\title{
SARS-CoV-2 Transmission between Mink (Neovison vison) and Humans, Denmark
}

\author{
Anne Sofie Hammer, Michelle Lauge Quaade, Thomas Bruun Rasmussen, \\ Jannik Fonager, Morten Rasmussen, Karin Mundbjerg, Louise Lohse, Bertel Strandbygaard, \\ Charlotte Sværke Jørgensen, Alonzo Alfaro-Núñez, Maiken Worsøe Rosenstierne, \\ Anette Boklund, Tariq Halasa, Anders Fomsgaard, Graham J. Belsham, Anette Bøtner
}

Severe acute respiratory syndrome coronavirus 2 has caused a pandemic in humans. Farmed mink (Neovison vison) are also susceptible. In Denmark, this virus has spread rapidly among farmed mink, resulting in some respiratory disease. Full-length virus genome sequencing revealed novel virus variants in mink. These variants subsequently appeared within the local human community.

Cevere acute respiratory syndrome coronavirus 2 $\checkmark$ (SARS-CoV-2) has caused the ongoing coronavirus disease (COVID-19) pandemic (1). Ferrets, cats, dogs, Syrian hamsters, and nonhuman primates can be infected with the virus and, in some cases, transmit it (2); however, other species, such as pigs and chickens, appear resistant $(3,4)$. Thus, the virus has a restricted host range. Infection with SARS-CoV-2 has occurred in farmed mink in the Netherlands (5).

In Denmark, there are $\approx 1,200$ mink farms (6). Because of contacts between persons with COVID-19 and mink farms, investigation of SARS-CoV-2 infection within mink in Denmark was undertaken. We documented 3 premises in the Northern Jutland region of Denmark with SARS-CoV-2-infected mink and analyzed virus transmission in mink and the local human community.

\section{The Study}

We collected blood and throat, nasal, and fecal swab samples from mink adults and kits (Table 1); we

Author affiliations: University of Copenhagen, Copenhagen, Denmark (A.S. Hammer, M.L. Quaade, K. Mundbjerg, A. Boklund, T. Halasa, G.J. Belsham, A. Bøtner); Statens Serum Institut, Copenhagen (T.B. Rasmussen, J. Fonager, M. Rasmussen, L. Lohse, B. Strandbygaard, C.S. Jørgensen, A. Alfaro-Núñez, M.W. Rosenstierne, A. Fomsgaard, A. Bøtner)

DOI: https://doi.org/10.3201/eid2702.203794 also sampled feed and air. We assayed viral RNA by quantitative reverse transcription PCR (qRT-PCR) (7). We performed SARS-CoV-2 Ab ELISA (Beijing Wantai Biological Pharmacy Enterprise, http://www. ystwt.cn) as described (R. Lassaunière et al., unpub. data, https://doi.org/10.1101/2020.04.09.20056325). SARS-CoV-2-positive RNA samples were sequenced and sequences aligned using Mafft (https://mafft. cbrc.jp/alignment/server/index.html). Phylogenetic analysis was performed in MEGA 10.1.7 (8) using the maximum-likelihood general time reversible plus invariant sites plus gamma ( 2 categories) method (9).

We selected mink farms for investigation because of COVID-19 in persons linked to them. During initial visits, we sampled 30 apparently healthy adult mink; we tested adults and kits in follow-up visits. We analyzed serum samples for SARS-CoV-2 antibodies and assayed swab samples for SARS-CoV-2 RNA (Table 1; Appendix, https://wwwnc.cdc.gov/EID/ article/27/2/20-3794-App1.pdf). At initial sampling, seroprevalence was high on farm 1 (>95\%) and farm $3(66 \%)$ but, in contrast, only $3 \%$ on farm 2 . However, after the infection spread widely on farm 2 , indicated by the increased prevalence of viral RNA (Table 1), a large increase in seroprevalence occurred, to $>95 \%$.

Air samples from farm 1 tested negative. However, on farms 2 and 3, multiple samples collected from exhaled air from mink or within $1 \mathrm{~m}$ of the cages scored positive, albeit with fairly high $(>31) C_{t}$ values. None of the air samples collected outside the houses were positive. Feed samples collected at each farm tested negative.

We also sequenced SARS-CoV-2 RNA from samples from each mink farm. The viruses found on farms 1-3 were very similar (Table 2). These sequences and those from humans (H1-H9) linked to 
Table 1. Summary of laboratory analyses of mink samples from 3 mink farms tested for severe acute respiratory syndrome coronavirus 2 in Denmark, June-July 2020*

\begin{tabular}{|c|c|c|c|c|c|c|}
\hline \multirow[b]{3}{*}{ Sample origin } & \multicolumn{4}{|c|}{ Test and specimen type, no. positive/no. tested (\%) } & \multirow{3}{*}{$\begin{array}{l}\text { Date of sample } \\
\text { collection }\end{array}$} & \multirow[b]{3}{*}{ Location } \\
\hline & \multirow{2}{*}{$\begin{array}{l}\text { ELISA } \\
\text { Serum }\end{array}$} & \multicolumn{3}{|c|}{ qRT-PCR } & & \\
\hline & & Throat swabs & Nasal swabs & Fecal swabs & & \\
\hline Live adult mink & $29 / 30(97)$ & NA & NA & $5 / 30(17)$ & 2020 Jun 14 & Farm 1 \\
\hline Dead adult mink & $\mathrm{NA}$ & NA & $4 / 4(100)$ & $3 / 4(75)^{\prime}$ & 2020 Jun 14 & Farm1 \\
\hline Live mink kits & $30 / 30(100)$ & $3 / 30(10)$ & $3 / 30(10)$ & $1 / 30(3)$ & 2020 Jun 17 & Farm 1 \\
\hline Live adult mink & $30 / 30(100)$ & $3 / 23(13)$ & NA & $0 / 23(0)$ & 2020 Jun 17 & Farm 1 \\
\hline Retested adult mink & $4 / 4(100)$ & $2 / 4(50)$ & $2 / 4(50)$ & $1 / 4(25)$ & 2020 Jun 17 & Farm 1 \\
\hline Live adult mink & $1 / 30(3)$ & NA & NA & $0 / 8(0)$ & 2020 Jun 18 & Farm 2 \\
\hline Dead adult mink & NA & $1 / 8(13)$ & NA & NA & 2020 Jun 18 & Farm 2 \\
\hline Live mink kits & $1 / 50(2)$ & $40 / 50(80)$ & $39 / 50(78)$ & NA & 2020 Jun 22 & Farm 2 \\
\hline Live adult mink & $3 / 50(6)$ & $46 / 50(92)$ & NA & NA & 2020 Jun 22 & Farm 2 \\
\hline Dead adult mink & $1 / 3(33)$ & $2 / 3(66)$ & $2 / 3(66)$ & NA & 2020 Jun 22 & Farm 2 \\
\hline Dead adult mink & NA & $3 / 3(100)$ & $3 / 3(100)$ & NA & 2020 Jun 30 & Farm 2 \\
\hline Live adult mink (retest) & $36 / 37(97)$ & $35 / 37(95)$ & $37 / 37(100)$ & NA & 2020 Jun 30 & Farm 2 \\
\hline Live adult mink & $20 / 30(67)$ & $6 / 6+(100)$ & NA & NA & 2020 Jun 30 & Farm 3 \\
\hline Dead adult mink & NA & $5 / 5(100)$ & NA & NA & 2020 Jun 30 & Farm 3 \\
\hline Live mink kits & $24 / 30(80)$ & $30 / 30(100)$ & $27 / 30(90)$ & NA & 2020 Jul 2 & Farm 3 \\
\hline Live adult mink & $23 / 30(77)$ & $30 / 30(100)$ & $26 / 30(87)$ & NA & 2020 Jul 2 & Farm 3 \\
\hline
\end{tabular}

Table 2. Location of $n$ t differences identified in genome sequences of selected severe acute respiratory syndrome coronavirus 2 samples from mink and humans in Denmark, June-July 2020, compared with Wuhan and clade 20B reference sequences*

\begin{tabular}{|c|c|c|c|c|c|c|c|c|c|c|c|c|}
\hline \multirow[b]{2}{*}{ Virus sample } & \multicolumn{12}{|c|}{ Genomic location and nt position } \\
\hline & $\begin{array}{c}5^{\prime} \\
\text { UTR } \\
241\end{array}$ & 3037 & 5421 & 9534 & 14408 & 15656 & 22920 & 23403 & $\begin{array}{c}\text { ORF3a } \\
25936 \\
\end{array}$ & 28881 & 28882 & 28883 \\
\hline NC045512 (Wuhan) & $\mathrm{C}$ & $\mathrm{C}$ & $A$ & $\mathrm{C}$ & $\mathrm{C}$ & $\mathrm{C}$ & $\mathrm{A}$ & $\mathrm{A}$ & $\mathrm{C}$ & G & $G$ & $G$ \\
\hline EPI_ISL_455326 20B & $\mathrm{T}$ & $\mathrm{T}$ & $A$ & $\mathrm{C}$ & $\mathrm{T}$ & C & $A$ & G & $\mathrm{C}$ & $A$ & $A$ & $\mathrm{C}$ \\
\hline Index case & $\mathrm{T}$ & T & $A$ & $\mathrm{C}$ & $\mathrm{T}$ & $\mathrm{T}$ & $A$ & G & ND & $A$ & $A$ & $\mathrm{C}$ \\
\hline Mink_KL14_Farm1 & $\mathrm{T}$ & $\mathrm{T}$ & A & $\mathrm{C}$ & $\mathrm{T}$ & $\mathrm{T}$ & A & $\mathrm{G}$ & $\mathrm{T}$ & A & A & $\mathrm{C}$ \\
\hline Mink_KL11_Farm1 & $\mathrm{T}$ & $\mathrm{T}$ & A & $\mathrm{C}$ & $\mathrm{T}$ & $\mathrm{T}$ & A & $\mathrm{G}$ & $\mathrm{T}$ & A & A & $\mathrm{C}$ \\
\hline Mink_AD3_Farm1 & $\mathrm{T}$ & $\mathrm{T}$ & G & $\mathrm{C}$ & $\mathrm{T}$ & $\mathrm{T}$ & $\mathrm{T}$ & G & $\mathrm{T}$ & $A$ & $A$ & $\mathrm{C}$ \\
\hline Mink_AD6_Farm1 & $\mathrm{T}$ & $\mathrm{T}$ & $A$ & $\mathrm{C}$ & $\mathrm{T}$ & $\mathrm{T}$ & $\mathrm{T}$ & G & $\mathrm{T}$ & $A$ & $A$ & $\mathrm{C}$ \\
\hline Mink_AL64_Farm1 & $\mathrm{T}$ & $\mathrm{T}$ & $A$ & $\mathrm{C}$ & $\mathrm{T}$ & $\mathrm{T}$ & A & G & $\mathrm{T}$ & $A$ & $A$ & $\mathrm{C}$ \\
\hline Mink_AL25_Farm1 & $\mathrm{T}$ & $\mathrm{T}$ & $A$ & $\mathrm{C}$ & $\mathrm{T}$ & $\mathrm{T}$ & $\mathrm{T}$ & G & $\mathrm{T}$ & $A$ & $A$ & $\mathrm{C}$ \\
\hline Mink_AL35_Farm3 & $\mathrm{T}$ & $\mathrm{T}$ & A & $\mathrm{C}$ & T & $\mathrm{T}$ & $\mathrm{T}$ & $\mathrm{G}$ & $\mathrm{T}$ & A & A & $\mathrm{C}$ \\
\hline $\mathrm{H} 1-\overline{\mathrm{H}} 7+\mathrm{H} \overline{9}$ & $\mathrm{~T}$ & $\mathrm{~T}$ & A & $\mathrm{C}$ & T & $\mathrm{T}$ & $\mathrm{T}$ & $\mathrm{G}$ & $\mathrm{T}$ & A & A & $\mathrm{C}$ \\
\hline $\mathrm{H} 8$ & $\mathrm{~T}$ & $\mathrm{~T}$ & A & $\mathrm{T}$ & T & $\mathrm{T}$ & $\mathrm{T}$ & $\mathrm{G}$ & $\mathrm{T}$ & A & A & $\mathrm{C}$ \\
\hline In NB01 (NL)§ & $\mathrm{T}$ & $\mathrm{T}$ & A & $\mathrm{C}$ & $\mathrm{T}$ & C & A & $\mathrm{G}$ & C & $\mathrm{G}$ & $\mathrm{G}$ & $\mathrm{G}$ \\
\hline In NB02 (NL)§ & $\mathrm{C}$ & $\mathrm{C}$ & A & $\mathrm{C}$ & C & $\mathrm{C}$ & $\mathrm{T}>\mathrm{A \#}$ & $A$ & $\mathrm{C}$ & $\mathrm{G}$ & $\mathrm{G}$ & $\mathrm{G}$ \\
\hline In NB03 $(\mathrm{NL}) \S$ & $\mathrm{T}$ & $\mathrm{T}$ & A & $\mathrm{C}$ & $\mathrm{T}$ & $\mathrm{C}$ & A & $\mathrm{G}$ & $\mathrm{T}$ & $\mathrm{G}$ & $\mathrm{G}$ & $\mathrm{G}$ \\
\hline In NB04 (NL)§ & $\mathrm{T}$ & $\mathrm{T}$ & A & $\mathrm{C}$ & $\mathrm{T}$ & $\mathrm{C}$ & $\mathrm{A}$ & $\mathrm{G}$ & C & $\mathrm{G}$ & $\mathrm{G}$ & G \\
\hline $\begin{array}{l}\text { Humans in Jutland (to } \\
2020 \text { Jul 1) }\end{array}$ & $\mathrm{T}$ & $\mathrm{T}$ & A & $\mathrm{C}$ & $\mathrm{T}$ & $\mathrm{C}>\mathrm{T}$ & $A>T$ & G & $\mathrm{C}>\mathrm{T}$ & $G>A$ & $G>A$ & $\mathrm{G}>\mathrm{C}$ \\
\hline $\begin{array}{l}\text { Encoded amino acid } \\
\text { change }\end{array}$ & NA & NA & $\begin{array}{l}\mathrm{I} 1719 \\
\mathrm{~V}\end{array}$ & $\underset{\mid}{\mathrm{T} 3083}$ & P314 & T730 & $\begin{array}{l}\text { Y453 } \\
\text { F }\end{array}$ & $\begin{array}{l}\mathrm{D} 614 \\
\mathrm{G}\end{array}$ & $\underset{Y}{\mathrm{H} 182}$ & $\underset{K}{\mathrm{R} 203}$ & $\underset{K}{\mathrm{R} 203}$ & $\begin{array}{c}\mathrm{G} 204 \\
\mathrm{R}\end{array}$ \\
\hline $\begin{array}{l}{ }^{*} \text { Red text indicates nt diffe } \\
\text { that differ from the clade } 2 \\
\text { applicable, as nt change in } \\
\dagger \text { The proportions of each } \\
\text { (https://wwwnc.cdc.gov/El } \\
\text { †nts present in farm } 2 \text { seq } \\
\text { §The mink sequences fron } \\
\text { TEncoded amino acid sub }\end{array}$ & $\begin{array}{l}\text { ences fr } \\
\text { O B and } \\
\text { the non } \\
\text { nt preser } \\
\text { J/article/ } \\
\text { lences o } \\
\text { the Net } \\
\text { titutions }\end{array}$ & $\begin{array}{l}\text { at each } \\
\text { ained fr } \\
\text { rlands } \\
\text { ith resi } \\
\end{array}$ & $\begin{array}{l}\text { Ihan refe } \\
\text {; gray sh } \\
\text { ion; ND, } \\
\text { of these p } \\
\text { 94-App1 } \\
\text { om throat } \\
\text { Iso differ } \\
\text { lue numb }\end{array}$ & $\begin{array}{l}\text { rence stra } \\
\text { ading indi } \\
\text { not detern } \\
\text { ositions i } \\
\text { pdf). } \\
\text { swab spe } \\
\text { at other l } \\
\text { er in each }\end{array}$ & $\begin{array}{l}\text { pink shac } \\
\text { es a refer } \\
\text { ed; NL, th } \\
\text { uman sec } \\
\text { ens on J } \\
\text { tions com } \\
\text { otein) cor }\end{array}$ & $\begin{array}{l}\text { ling indica } \\
\text { ence clad } \\
\text { e Netherl } \\
\text { uences in } \\
\text { une 22, } 2 \\
\text { pared wit } \\
\text { npared to }\end{array}$ & $\begin{array}{l}\text { nt chand } \\
\text { OB seque } \\
\text { Is; ORF, } \\
\text { tland are } \\
\text { (derived } \\
\text { ne Wuhar } \\
\text { uhan refe }\end{array}$ & $\begin{array}{l}\text { es detect } \\
\text { ince and t } \\
\text { open read } \\
\text { shown in } \\
\text { from } 20 \text { o } \\
\text { sequenc } \\
\text { rence stra }\end{array}$ & $\begin{array}{l}\text { n mink an } \\
\text { luman ind } \\
\text { frame. } \\
\text { oendix Ta } \\
\text { t mink anc } \\
\text { ). } \\
\text { re indicat }\end{array}$ & $\begin{array}{l}\text { human c } \\
\text { case sequ } \\
1 \\
\text { kits). }\end{array}$ & $\begin{array}{l}\text { ntacts }(\mathrm{H} \\
\text { ence. NA }\end{array}$ & $\begin{array}{l}1-\mathrm{H} 9) \\
\text { not }\end{array}$ \\
\hline
\end{tabular}


the infected farms grouped within the European 20B clade of the global SARS-CoV-2 tree $(10,11)$ (Figure; Appendix Table 1). We deposited the SARS-CoV-2 genome sequences of virus from farm 1 (SARS-CoV-2/mink/DK/AD3_Farm1/2020) in GenBank (accession nos. MT919525-36). The sequences closely matched those of a human case, diagnosed in mid-May, with a direct epidemiologic link to farm 1 . This index sequence (only $91 \%$ complete) matched the mink viruses at nt 15656 (rare globally) but had A at nt 22920 (Table 2). The nt 25936 in the index case could not be determined. The local phylogeny (Appendix Figure) showed that mink sequences from farm 1 fell into 3 subclusters (defined by the nucleotide changes at positions 5421 and 22920), but sequences from linked humans (H1-H9) and mink in farms 2 and 3 were within subcluster 2 (Appendix Figure).

We found 9 to $11 \mathrm{nt}$ differences (mainly nonsynonymous) between the mink sequences in Denmark and the Wuhan-Hu-1 reference sequence (Table 2). One mutation at nt 23403 (resulting in substitution
D614G in the spike protein) was present in all sequences from mink in Denmark and the Netherlands, except for NB02 from the Netherlands (Table 2 ) and was predominant in the human population in Jutland (Appendix Table 1) and globally (12). However, another mutation (nt C25936T [as cDNA] encoding H182 to Y within ORF3a) appeared in all mink sequences from Denmark (Table 2) and in human cases (H1-H9) linked to them. This change was not found in human SARS-CoV-2 sequences from Jutland before June 10, 2020 (Appendix Table 1 ), but reached $\approx 40 \%$ frequency during June 10 -July 1, 2020 (Table 2; Appendix Table 2). This mutation has been found only rarely in other SARS-CoV-2 sequences (11) (Appendix Table 1) but was in mink farm NB03 from the Netherlands (SARS-CoV-2/ mink/NED/NB03_index/2020; GenBank accession no. MT457400.1).

Another mutation in the spike gene (A22920T, encoding $\mathrm{Y} 453$ to F) was present in 4 of 8 sequences from farm 1, in all sequences from farms 2 and 3 , and in 5 of 6 sequences from farm NB02 in the

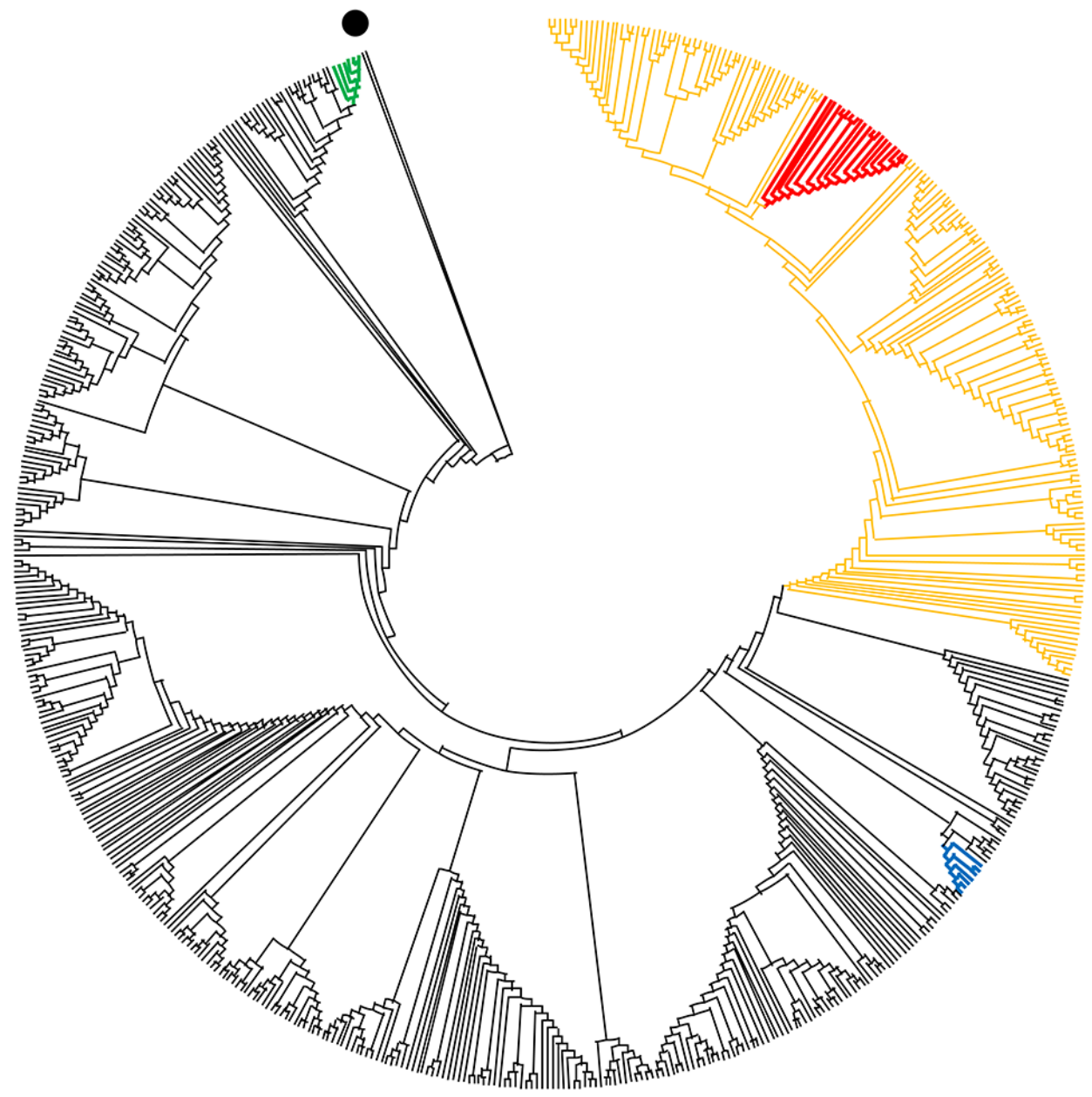

Figure. Phylogenetic tree showing relationships between genome sequences of severe acute respiratory syndrome coronavirus 2 from mink and humans at 3 mink farms in Denmark, June-July 2020 (red), and selected global full-length genome sequences. Black dot indicates Wuhan reference sequence NC_045512.2; green indicates mink farm NB02 in the Netherlands; blue indicates mink farms NB01, NB03, and NB04 in the Netherlands; orange indicates clade 20B. 
Netherlands (5). This change was not in the index case or the human population anywhere before June 10 but was subsequently detected in farm-linked humans (H1-H9) and in Jutland (Table 2; Appendix Table 2). Finally, the mutation in the open reading frame $1 \mathrm{~b}$ gene (C15656T, encoding T730 to I) was present only in mink/human sequences from Denmark (Table 2) and a sequence from New Zealand (Appendix Table 1).

\section{Conclusions}

A high proportion of mink on farms can be infected with SARS-CoV-2 within a few days, which may provide major virus exposure to persons working with mink. The infections we describe here occurred with little clinical disease or increase in death (Appendix), making it difficult to detect the spread of infection; thus, mink farms could represent a serious, unrecognized animal reservoir for SARS-CoV-2. There is no evidence for spread of the virus outside of farm buildings, either in Denmark or in the Netherlands (5), except by infected persons. However, there appears to be some risk of virus transmission to persons working with infected mink as well as for their contacts and thus, indirectly, for the public.

On farm 1, the virus had probably been introduced some weeks before detection (Table 1). On farm 2, the low frequency $(4 \%)$ of seropositivity and the high proportion of qRT-PCR positive animals at second sampling (Table 1) suggested that the virus had been recently introduced but was spreading. Indeed, a third sampling (8 days later) showed a much higher seroprevalence $(>90 \%)$. Conceivably, the variant viruses that appeared in farm 1 and spread to farms 2 and 3 may be better adapted to mink and thus able to transmit rapidly. The infection at farm 3 was detected relatively late, with a high seroprevalence $(66 \%)$ at first visit.

A likely scenario for the spread of infection in mink in Denmark is that the index human casepatient, who had nt T15656 introduced it into farm 1. Initially, we observed sequence heterogeneity at nt 22920 in mink on farm 1, but subsequently, we detected only the variant form (T22920) on farms 2 and 3 and in subsequent linked human cases (H1-H9) (Table 2). Remarkably, this heterogeneity also occurred on farm NB02 in the Netherlands. This change, possibly together with the mutation at nt 25936 (Table 2 ), may represent virus adaptation. It is not yet established whether these changes confer advantages in mink, but the variant viruses in farm 2 spread rapidly. It seems that the variant viruses on farm 1 spread to $\geq 1$ human and were then transmitted, presumably by human-human contact, to other persons and to farms 2 and 3. The change at nt 22920 results in substitution Y453F in the S-protein (Table 2). This Y-residue, within the receptor-binding motif of the S-protein, is highly conserved among SARSrelated coronaviruses and is close to residue L455 that is critical for interaction with the cellular ACE2 receptor (13).

\section{Acknowledgments}

We thank Mads Albertsen for guidance with Nanopore sequencing and Henrik B. Krarup for providing human samples containing SARS-CoV-2. We gratefully acknowledge the provision of genetic sequence data shared via GISAID (https:/ / www.gisaid.org; see Appendix Table 3, https://wwwnc.cdc.gov/EID/article/27/2/20-3794-App1. pdf). We also thank Amalie E. Bedsted and Thea Kristensen for careful reading of the manuscript.

\section{About the Author}

Dr. Hammer, an associate professor at the University of Copenhagen, is a veterinary pathologist with special interest and expertise in pathological methods applied in diagnostics, research, and surveillance of diseases in fur animals and wildlife. Her research focus has been mainly on viral diseases of carnivorous species.

\section{References}

1. Johns Hopkins University. Coronavirus resource center. 2020 [cited 2020 Nov 11]. https:/ / coronavirus.jhu.edu

2. Cohen J. From mice to monkeys, animals studied for coronavirus answers. Science. 2020;368:221-2. https:// doi.org/10.1126/science.368.6488.221

3. Schlottau K, Rissmann M, Graaf A, Schön J, Sehl J, Wylezich C, et al. SARS-CoV-2 in fruit bats, ferrets, pigs, and chickens: an experimental transmission study. Lancet Microbe. 2020;1:e218-25. https://doi.org/10.1016/ S2666-5247(20)30089-6

4. Shi J, Wen Z, Zhong G, Yang H, Wang C, Huang B, et al. Susceptibility of ferrets, cats, dogs, and other domesticated animals to SARS-coronavirus 2. Science. 2020;368:1016-20. https://doi.org/10.1126/science.abb7015

5. Oreshkova N, Molenaar RJ, Vreman S, Harders F, Oude Munnink BB, Hakze-van der Honing RW, et al. SARS-CoV-2 infection in farmed minks, the Netherlands, April and May 2020. Euro Surveill. 2020;25:2001005. https://doi.org/10.2807/1560-7917.ES.2020.25.23.2001005

6. Miljø-og Fødevareministeriet, Fødevarestyrelsen [in Danish]. 2020 [cited 2020 Nov 11]. https://chr.fvst.dk/chri/faces/ frontpage?_adf.ctrl-state=31prh7gzs_3

7. Corman VM, Landt O, Kaiser M, Molenkamp R, Meijer A, Chu DK, et al. Detection of 2019 novel coronavirus (2019-nCoV) by real-time RT-PCR. Euro Surveill. 2020;25:2000045. https:// doi.org/10.2807/1560-7917. ES.2020.25.3.2000045

8. Kumar S, Stecher G, Li M, Knyaz C, Tamura K. MEGA X: Molecular Evolutionary Genetics Analysis across computing platforms. Mol Biol Evol. 2018;35:1547-9. https://doi.org/10.1093/molbev/msy096 
9. Nei M, Kumar S. Molecular evolution and phylogenetics. Oxford (UK): Oxford University Press; 2000.

10. Alm E, Broberg EK, Connor T, Hodcroft EB, Komissarov AB, Maurer-Stroh S, et al. Geographical and temporal distribution of SARS-CoV-2 clades in the WHO European Region, January to June 2020. Euro Surveill. 2020;25: 2001410. https:/ / doi.org/10.2807/1560-7917. ES.2020.25.32.2001410

11. Nextclade. 2020 [cited 2020 Nov 11]. https:/ / clades. nextstrain.org

12. Korber B, Fischer WM, Gnanakaran S, Yoon H, Theiler J, Abfalterer W, et al. Tracking changes in SARS-CoV-2 spike: evidence that D614G increases infectivity of the COVD-19 virus. Cell. 2020;182:812-27.e19. https:/ / doi.org/10.1016/ j.cell.2020.06.043

13. Shang J, Ye G, Shi K, Wan Y, Luo C, Aihara H, et al. Structural basis of receptor recognition by SARS-CoV-2. Nature. 2020;581:221-4. https:/ / doi.org/10.1038/s41586-020-2179-y

Address for correspondence: Anette Bøtner, Department of Veterinary and Animal Sciences, University of Copenhagen, Grønnegårdsvej 15, 1870 Frederiksberg C, Denmark; email: aneb@sund.ku.dk
- Surveillance of Leprosy in Kiribati, 1935-2017

- Biphasic Outbreak of Invasive Group A Streptococcus Disease in Eldercare Facility, New Zealand

- Epidemiology of Tick-Borne Relapsing Fever in Endemic Area, Spain

- Food Safety and Invasive Cronobacter Infections during Early Infancy, 1961-2018

- Clinical Outcomes of Patients Treated for Candida auris Infections in a Multisite Health System, Illinois, USA

- Mosquito Control Activities during Local Transmission of Zika Virus, Miami-Dade County, Florida, USA, 2016

- Blastomycosis in Minnesota, USA, 1999-2018

- Effectiveness of Live Poultry Market Interventions on Human Infection with Avian Influenza $A(H 7 N 9)$ Virus, China

- Nationwide Monitoring for Plasmodium falciparum Drug-Resistance Alleles to Chloroquine, Sulfadoxine, and Pyrimethamine, Haiti, 2016-2017

- Systematic Review and MetaAnalysis of Sex Differences in Social Contact Patterns and Implications for Tuberculosis Transmission and Control

- Effects of Air Pollution and Other Environmental Exposures on Estimates of Severe Influenza Illness, Washington, USA

- Epidemiologic and Clinical Progression of Lobomycosis among Kaiabi Indians, Brazil, 1965-2019

\section{May 2020} iratory Viruses

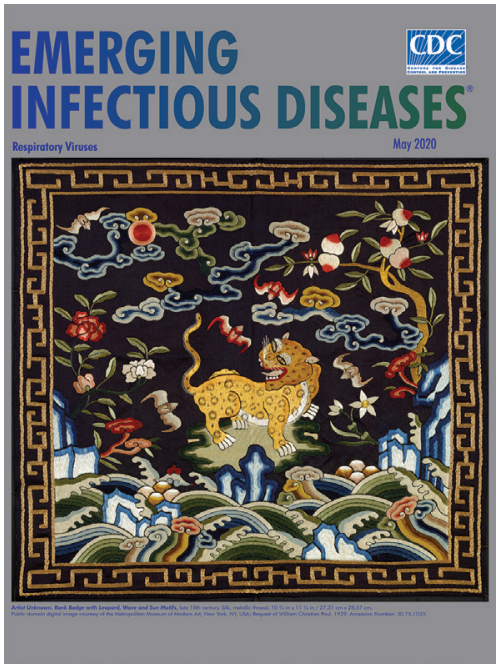

- Rhizopus microsporus Infections Associated with Surgical Procedures, Argentina, 2006-2014

- Zika Virus Circulation in Mali

- Possible Transmission Mechanisms of Mixed Mycobacterium tuberculosis Infection in High HIV Prevalence Country, Botswana

- Nonpharmaceutical Measures for Pandemic Influenza in Nonhealthcare Settings-International TravelRelated Measures

- Nonpharmaceutical Measures for Pandemic Influenza in Nonhealthcare Settings-Personal Protective and Environmental Measures

- Nonpharmaceutical Measures for Pandemic Influenza in Nonhealthcare Settings-Social Distancing Measures
- Candidatus Rickettsia xinyangensis as Cause of Spotted Fever Group Rickettsiosis, Xinyang, China, 2015

- Pretreatment Out-of-Pocket Expenses for Presumptive Multidrug-Resistant Tuberculosis Patients, India, 2016-2017

- Capybara and Brush Cutter Involvement in Q Fever Outbreak in Remote Area of Amazon Rain Forest, French Guiana, 2014

- Women's Awareness and Healthcare Provider Discussions about Zika Virus during Pregnancy, United States, 2016-2017

- Genetic Characterization of Japanese Encephalitis Virus Genotype 5 Isolated from Patient, South Korea, 2015

- Update on Ebola Treatment Center Costs and Sustainability, United States, 2019

- A Neighbor-Based Approach to Identify Tuberculosis Exposure, the Kopanyo Study

- Species Distribution and Isolation Frequency of Nontuberculous Mycobacteria, Uruguay

- Crimean-Congo Hemorrhagic Fever Virus Endemicity in United Arab Emirates, 2019

- Zika Inquiries Made to the CDC-INFO System, December 2015-September 2017

- Serologic Detection of Middle East Respiratory Syndrome Coronavirus Functional Antibodies

- Novel Ehrlichia Strain Infecting Cattle Tick Amblyomma neumanni, Argentina, 2018
EMERGING INFECTIOUS DISEASES
To revisit the May 2020 issue, go to:

\section{https://wwwnc.cdc.gov/eid/articles/issue/26/5/table-of-contents}

